\title{
Deficiency of the Copper Chaperone for Superoxide Dismutase Increases Amyloid- $\beta$ Production
}

\author{
Emma H. Gray ${ }^{a}$, Kurt J. De Vos ${ }^{\mathrm{a}}$, Colin Dingwalla,b, Michael S. Perkinton ${ }^{\mathrm{a}}$ and \\ Christopher C.J. Miller ${ }^{\mathrm{a}, *}$ \\ ${ }^{\mathrm{a}}$ MRC Centre for Neurodegeneration Research, Institute of Psychiatry, King's College London, UK \\ ${ }^{\mathrm{b}}$ Pharmaceutical Sciences Research Division, King's College London, UK
}

Handling Associate Editor: Thomas Shea

Accepted 13 May 2010

\begin{abstract}
The copper chaperone for superoxide dismutase (CCS) binds to both the $\beta$-site A $\beta \mathrm{PP}$ cleaving enzyme (BACE1) and to the neuronal adaptor protein $\mathrm{X} 11 \alpha$. BACE1 initiates $\mathrm{A} \beta \mathrm{PP}$ processing to produce the amyloid- $\beta$ (A $\beta$ ) peptide deposited in the brains of Alzheimer's disease patients. X11 $\alpha$ also interacts directly with $\mathrm{A} \beta \mathrm{PP}$ to inhibit $\mathrm{A} \beta$ production. However, whether $\mathrm{CCS}$ affects $\mathrm{A} \beta \mathrm{PP}$ processing and $\mathrm{A} \beta$ production is not known. Here we show that loss of CCS increases $\mathrm{A} \beta$ production in both CCS knockout neurons and CCS siRNA-treated SHSY5Y cells and that this involves increased A $\beta$ PP processing at the BACE1 site.
\end{abstract}

Keywords: BACE1, copper, copper chaperone for superoxide dismutase, $\mathrm{Cu} / \mathrm{Zn}$ superoxide dismutase, munc18 interacting protein-1, X11 $\alpha$

\section{INTRODUCTION}

Altered copper homeostasis is strongly implicated in Alzheimer's disease. Copper is enriched in amyloid plaques and binds to both the amyloid- $\beta$ protein precursor $(\mathrm{A} \beta \mathrm{PP})$ and to amyloid- $\beta(\mathrm{A} \beta)$, and copper binding to $\mathrm{A} \beta$ can promote its aggregation into amyloid fibrils. Moreover, changes in copper metabolism including copper binding to $\mathrm{A} \beta$ are linked to the generation of reactive oxygen species and to increased ox-

\footnotetext{
*Correspondence to: Chris Miller, MRC Centre for Neurodegeneration Research, Department of Neuroscience PO37, Institute of Psychiatry, De Crespigny Park, Denmark Hill, London, SE5 8AF, UK. Tel.: +44 (0)2078480393; Fax: +44 (0)2077080017; E-mail: chris.miller@kcl.ac.uk.
}

idative stress in the brains of Alzheimer's disease patients (see reviews [1,2]). While copper is an essential nutrient, the ability of copper ions to exchange electrons makes copper highly toxic and so its intracellular levels are tightly regulated via a variety of transporters, chelators, and chaperones [3]. CCS is a copper-binding protein that delivers copper to several proteins including the antioxidant enzyme $\mathrm{Cu} / \mathrm{Zn}$ superoxide dismutase (SOD1), X-linked inhibitor of apoptosis protein (XIAP), and possibly BACE1 [4-6].

A number of lines of evidence suggest that CCS may impact on $\mathrm{A} \beta \mathrm{PP}$ processing and $\mathrm{A} \beta$ production in Alzheimer's disease. Firstly, CCS binds to the intracellular domain of BACE1 and may deliver copper to BACE1 [4]. BACE1 is a key enzyme required for the processing of $\mathrm{A} \beta \mathrm{PP}$ to produce $\mathrm{A} \beta$ [7]. Secondly, 
CCS binds to the neuronal adaptor protein $\mathrm{X} 11 \alpha$ (also known as munc-18 interacting protein-1) [8]. X11 $\alpha$ also interacts directly with $\mathrm{A} \beta \mathrm{PP}$ and overexpression of $\mathrm{X} 11 \alpha$ inhibits $\mathrm{A} \beta$ production in $\mathrm{A} \beta \mathrm{PP}$ transgenic mice [9-11]. Finally, modulating SOD1 levels alters $\mathrm{A} \beta$ production [12]. However, whether CCS affects $\mathrm{A} \beta$ production is not known.

To address this question, we monitored how loss of CCS influences neuronal $\mathrm{A} \beta$ production via analyses of neurons derived from CCS homozygous and heterozygous knockout, and wild-type littermate mice (CCS-/-; CCS+/-; CCS+/+) [5]. The levels of both secreted and intracellular $\mathrm{A} \beta$ were significantly higher in CCS-/- compared to CCS+/+ neurons (Fig. 1A). Moreover, elevated levels of secreted $\mathrm{A} \beta$ were also detected in $\mathrm{CCS}+/$ - neurons and this was significantly less than in CCS-/- neurons (Fig. 1A). CCS+/- neurons displayed the predicted $50 \%$ reduction in CCS protein levels (Fig. 1B).

We also assayed how loss of CCS influenced $A \beta$ production in SHSY5Y neuroblastoma cells stably expressing human $\mathrm{A} \beta \mathrm{PP}-695$ isoform (SHSY5Y-A $\beta \mathrm{PP}$ ); CCS was depleted by use of siRNAs. The higher levels of $\mathrm{A} \beta$ in SHSY $5 \mathrm{Y}-\mathrm{A} \beta \mathrm{PP}$ cells enabled robust determination of both $\mathrm{A} \beta_{1-40}$ and $\mathrm{A} \beta_{1-42}$ isoforms. Two different CCS siRNAs both significantly increased secreted $\mathrm{A} \beta_{1-40}$ and $\mathrm{A} \beta_{1-42}$ levels, and increased the level of intracellular $\mathrm{A} \beta_{1-40}$; one siRNA (the most potent at reducing CCS levels; siRNA\#7) also increased intracellular $\mathrm{A} \beta_{1-42}$ levels (Fig. 1C). The two CCS siRNAs reduced CCS levels to approximately $10 \%$ (CCS siRNA\#7) and 25\% (CCS siRNA\#8) of control levels (Fig. 2A). Thus, loss of CCS increases A $\beta$ production in two different experimental systems. Cell counts revealed no loss of viability in either CCS-/neurons or CCS siRNA treated SHSY5Y-A $\beta$ PP cells compared to controls. Likewise no noticeable morphological changes were observed in CCS depleted cells.

Processing of A $\beta$ PP by BACE 1 and $\gamma$-secretase releases $\mathrm{A} \beta$, whereas $\alpha$ - and $\gamma$-secretase processing precludes $\mathrm{A} \beta$ production [13]. To determine whether loss of CCS induced changes in expression of $\mathrm{A} \beta \mathrm{PP}$ or its major secretases, we probed immunoblots of $\mathrm{CCS}+/+$ and CCS-/- mouse neurons, and siRNA treated SHSY5Y-A $\beta$ PP cells for A $\beta$ PP, ADAM10 ( $\alpha$ secretase), BACE1, and presenilin-1 ( $\gamma$-secretase component). However, loss of CCS did not induce detectable changes in the levels of any of these proteins (Fig. 2A).

We next investigated whether loss of CCS influenced processing of $\mathrm{A} \beta \mathrm{PP}$ at the BACE 1 or $\alpha$-secretase cleav- age sites. To do so we monitored the levels of secreted ectodomain fragments of $\mathrm{A} \beta \mathrm{PP}$ (sA $\beta \mathrm{PP}$ ) present in the culture medium from SHSY5Y-A $\beta$ PP cells by immunoblotting. Processing of $\mathrm{A} \beta \mathrm{PP}$ by BACE 1 and $\alpha$-secretase induces release of $\operatorname{sA} \beta \mathrm{PP} \beta$ and $\operatorname{sA} \beta \mathrm{PP} \alpha$ fragments respectively into the media. siRNA knockdown of CCS induced significant increases in the levels of both total $\mathrm{sA} \beta \mathrm{PP}$ and $\mathrm{sA} \beta \mathrm{PP} \beta$; no change in sA $\beta \mathrm{PP} \alpha$ levels were detected (Fig. $2 \mathrm{~B}, \mathrm{C}$ ).

Our results described here demonstrate that loss of CCS increases $\mathrm{A} \beta$ production and that this is accompanied by increased processing of $\mathrm{A} \beta \mathrm{PP}$ at the BACE1 site. The precise mechanisms by which this occurs are unclear. Oxidative stress increases BACE1 expression [14-16] but we did not detect any changes in BACE1 levels in either CCS siRNA-treated or CCS knockout cells. Indeed, although CCS loss can influence SOD1 activity, there are other routes whereby SOD1 can obtain copper for its antioxidant activity [17]. Alternatively, CCS may increase $\mathrm{A} \beta$ production via an effect on BACE1 activity, trafficking, or its association with $\mathrm{A} \beta \mathrm{PP}$. The intracellular domain of BACE1 that binds CCS is known to mediate its trafficking [7,18]. A further possibility is that CCS delivers copper to BACE1 since its intracellular domain binds a single copper atom and that bound copper modulates BACE1 activity or trafficking [4]. Copper is known to influence the activity and trafficking of other proteins [3]. Finally, CCS may influence $\mathrm{A} \beta \mathrm{PP}$ and/or $\mathrm{BACE} 1$ trafficking via its binding to $\mathrm{X} 11 \alpha$. Overexpression of $\mathrm{X} 11 \alpha$ inhibits $\mathrm{A} \beta$ production and $\mathrm{X} 11 \alpha$ is known to be involved in protein trafficking including the trafficking of $\mathrm{A} \beta \mathrm{PP}$ [9,19-21]. Whatever the precise mechanism, our results demonstrate a role for CCS in $\mathrm{BACE} 1$ mediated processing of $\mathrm{A} \beta \mathrm{PP}$ and production of $\mathrm{A} \beta$.

\section{ACKNOWLEDGMENTS}

Supported by grants from the Wellcome Trust, MRC, Alzheimer's Association, and Alzheimer's Research Trust. We thank Philip Wong, Department of Pathology, The Johns Hopkins University School of Medicine, Baltimore USA for supplying CCS knockout mice and GSK for antibody 1 A9.

Authors' disclosures available online (http://www.jalz.com/disclosures/view.php?id=453). 
A

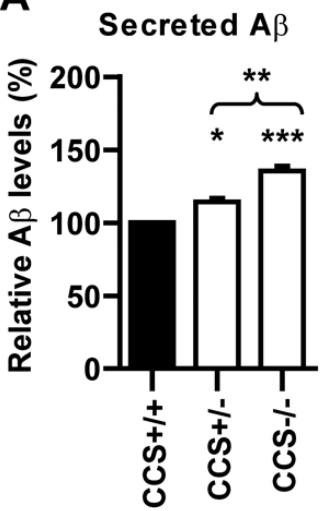

C

\section{Secreted A $\beta(1-40)$}

\section{Intracellular $A \beta$}

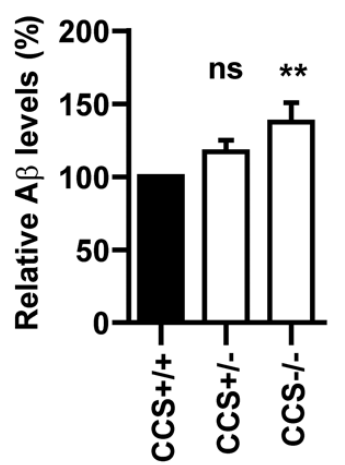

B

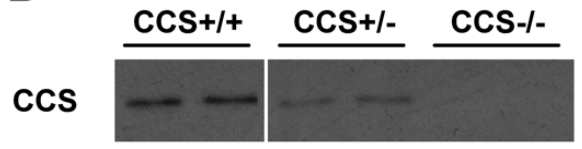

Actin

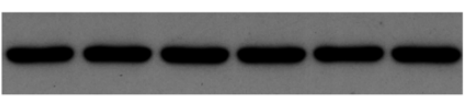

\section{Intracellular \\ A $\beta(1-40)$}

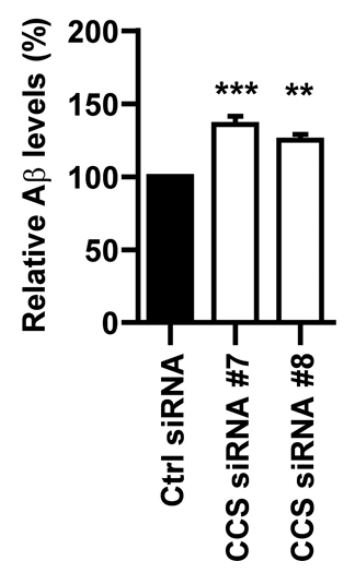

Secreted

A $\beta$ (1-42)

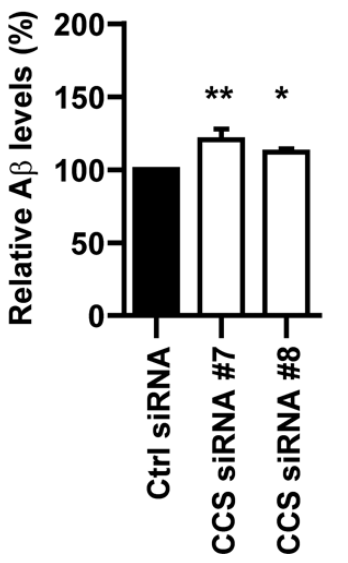

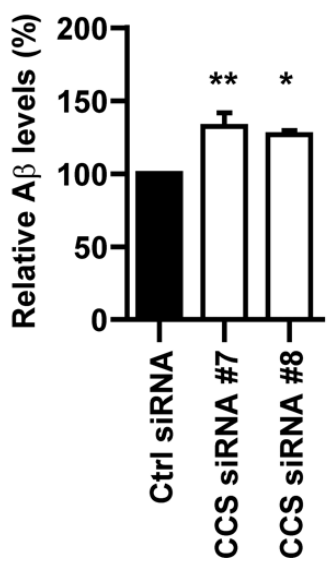

\section{Intracellular \\ A $\beta$ (1-42)}

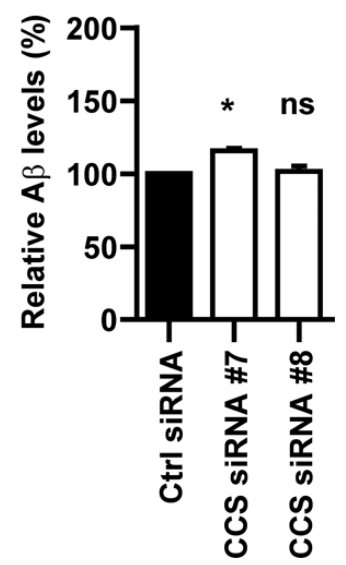

Fig. 1. Loss of CCS increases A $\beta$ production in both CCS knockout neurons (A) and SHSY5Y-A $\beta$ PP siRNA treated cells (C). (A) Male and female $\mathrm{CCS}+/$ - mice were mated and cortical neurons prepared from E14.5 embryos and cultured as described [22]. Samples were harvested for analyses at DIV5. Cultures were genotyped by PCR analyses of the remaining carcasses as described [5]. Secreted and intracellular A $\beta_{1-40}$ levels were determined using mouse/rat high specific A $\beta$ ELISA (IBL International) according to the manufacturer's instructions. Secreted $\mathrm{A} \beta$ levels were significantly increased in both CCS-/- and CCS+/- compared to CCS $+/+$ neurons; secreted A $\beta$ levels in CCS-/- neurons were also significantly increased compared to $\mathrm{CCS}+/-$ neurons. Intracellular $\mathrm{A} \beta$ levels were significantly increased in CCS-/- neurons. Secreted and intracellular $\mathrm{A} \beta$ levels in CCS $+/+$ neurons were $230 \mathrm{pg} / \mathrm{ml}$ and $32 \mathrm{pg} / \mathrm{ml}$ respectively. (B) Immunoblot showing the levels of CCS in CCS+/+, $\mathrm{CCS}+/$ - and CCS-/- neurons; two different samples are shown for each genotype (line in CCS immunoblot indicates removal of portion of the blot for clarity but the samples shown are all from the same blot and are presented at the same exposure). Analyses of the signal intensities for CCS in this and other samples (Fig. 2A) were performed as described [23] and revealed an approximate 50\% reduction in CCS levels in CCS+/- compared to CCS+/+ neurons. Actin levels are shown as a loading control. CCS was detected using antibody FL-274 (Santa Cruz); actin using antibody AC-40 (Sigma). (C) Stably expressing SHSY5Y-A $\beta$ PP cells were prepared by transfection of A $\beta$ PP in plasmid pCIneo (Promega) and selection with G418. For siRNA knockdown experiments, G418 was removed and cells transfected with non-targeting control or CCS siRNAs (On-TARGETplus; Dharmacon) using Lipofectamine 2000 (Invitrogen) according to manufacturer's instructions. 48 hours post-transfection, the media was replaced with Opti-MEM (Invitrogen) and the cells harvested for analyses after a further 48 hours in culture. siRNA sequences were: CCS siRNA\#7 5'-GGAAUCACUUUAACCCUGA-3', CCS siRNA\#8 5'-GGCCAUCCCUUAUCCAAGA-3'. Secreted and intracellular $\mathrm{A} \beta_{1-40}$ and $\mathrm{A} \beta_{1-42}$ levels were determined using TKHS-ELISA kits (Millipore) according to the manufacturer's instructions. Both CCS siRNAs significantly increased secreted $\mathrm{A} \beta_{1-40}$ and $\mathrm{A} \beta_{1-42}$, and intracellular $\mathrm{A} \beta_{1-40}$ levels; CCS siRNA\#7 (which induced a greater reduction in CCS levels) also significantly increased intracellular $\mathrm{A} \beta_{1-42}$ levels. Secreted and intracellular $\mathrm{A} \beta$ levels in control cells were: secreted $\mathrm{A} \beta_{1-40} 1327 \mathrm{pg} / \mathrm{ml}$; secreted $\mathrm{A} \beta_{1-42} 316 \mathrm{pg} / \mathrm{ml}$; intracellular $\mathrm{A} \beta_{1-40} 31 \mathrm{pg} / \mathrm{ml}$; intracellular $\mathrm{A} \beta_{1-42} 8 \mathrm{pg} / \mathrm{ml}$. Data were analysed using one-way ANOVA tests with LSD post-hoc test; * indicate significant differences between CCS-/- and CCS+/+ in (A) and between control and CCS siRNAs in (B). ${ }^{*} p<0.05$; ${ }^{*} p<0.01$; ${ }^{*} * p<0.001$; not significant (ns). $n=6-8$ for individual experiments which were repeated a further two times; data are normalized to controls. Error bars are SEM. 
A
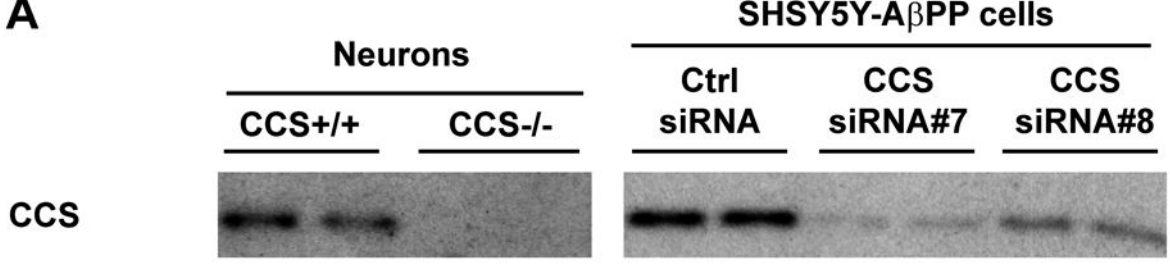

A $\beta \mathbf{P P}$
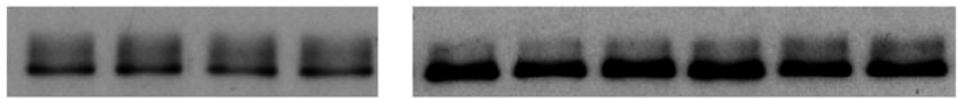

ADAM10
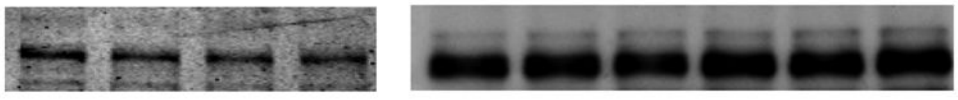

BACE1
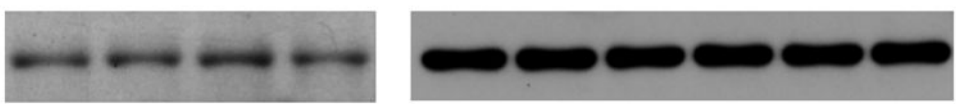

Presenilin-1
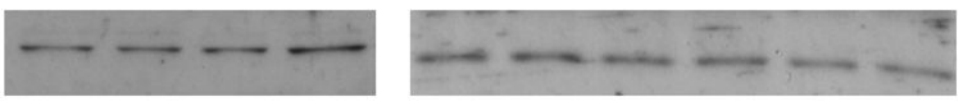

Actin
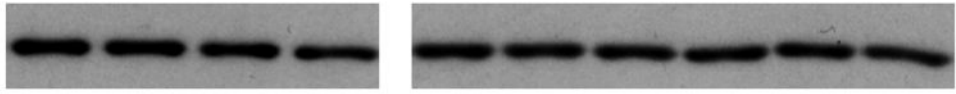

B

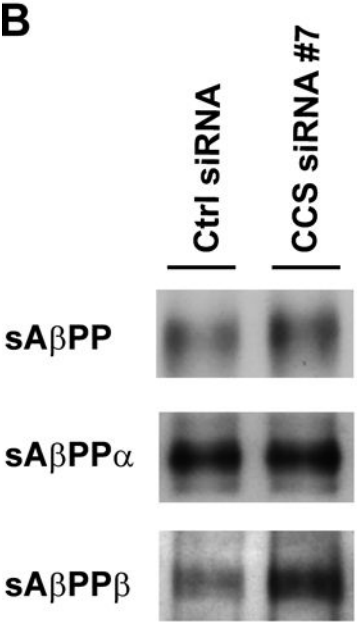

C

sA $\beta$ PP

$\mathbf{s A} \beta \mathbf{P P} \alpha$

sA $\beta \mathbf{P P} \beta$
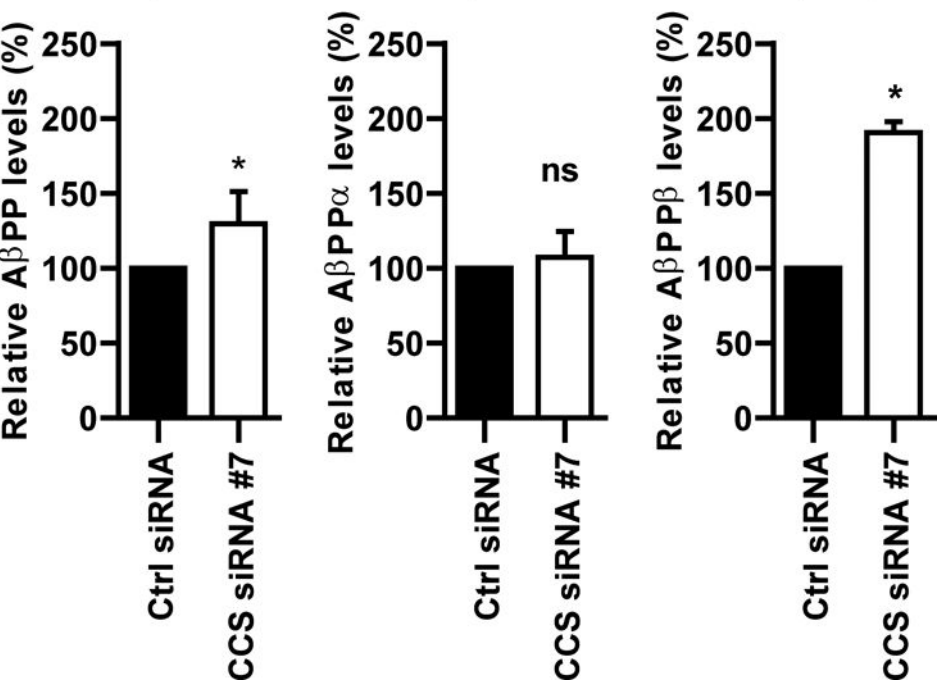

Fig. 2. Loss of CCS does not induce detectable changes in the steady state levels of $A \beta P P$ or its secretases but selectively increases processing of $\mathrm{A} \beta \mathrm{PP}$ at the BACE1 site. (A) Immunoblots of total cell lysates from SHSY5Y-A $\beta$ PP siRNA treated cells and CCS knockout neurons probed for A $\beta$ PP, ADAM10, BACE1, and presenilin-1. Two different samples are shown for each treatment/genotype but two further samples were analyzed with similar results. Also shown are immunblots for CCS and as a loading control, actin. A $\beta$ PP was detected using a C-terminal antibody [24], presenilin-1 using an N-terminal antibody [25], the ADAM10 antibody was from Calbiochem and the BACE1 antibody (EE-17) was from Sigma. (B) Immunoblots for total $\mathrm{sA} \beta \mathrm{PP}, \mathrm{sA} \beta \mathrm{PP} \alpha$, and $\mathrm{sA} \beta \mathrm{PP} \beta$ in conditioned media from SHSY5Y-A $\beta$ PP expressing cells treated with control or CCS siRNA\#7. Total $\mathrm{sA} \beta \mathrm{PP}$ was detected using antibody $22 \mathrm{C} 11$ (Millipore), $\mathrm{sA} \beta \mathrm{PP} \alpha$ was detected using antibody $6 \mathrm{E} 10$ (Covance) and $\mathrm{sA} \beta \mathrm{PP} \beta$ detected using antibody 1A9 that detects the sA $\beta$ PP neo-epitope generated after cleavage of A $\beta$ PP by BACE1 [26]. Quantification of signal intensities on the immunoblots (performed as described [23]) are shown in (C). CCS knockdown increased total sA $\beta \mathrm{PP}$ and sA $\beta \mathrm{PP} \beta$ levels but had no effect on $\mathrm{sA} \beta \mathrm{PP} \alpha$ levels. The larger relative increase in $\mathrm{sA} \beta \mathrm{PP} \beta$ compared to total $\mathrm{sA} \beta \mathrm{PP}$ levels in CCS depleted cells is consistent with known $\mathrm{A} \beta \mathrm{PP}$ processing events; most $\mathrm{A} \beta \mathrm{PP}$ is cleaved by $\alpha$-secretase and not $\mathrm{BACE} 1$ such that $\mathrm{AA} \beta \mathrm{PP} \alpha$ is the major and $\mathrm{sA} \beta \mathrm{PP} \beta$ the minor species secreted by cells. Data analysed by t-test; $* p<0.05$; not significant (ns). $n=3$; error bars are SEM. 


\section{REFERENCES}

[1] Zhu X, Su B, Wang X, Smith MA, Perry G (2007) Causes of oxidative stress in Alzheimer disease. Cell Mol Life Sci 64, 2202-2210.

[2] Hung YH, Bush AI, Cherny RA (2010) Copper in the brain and Alzheimer's disease. J Biol Inorg Chem 15, 61-76.

[3] Banci L, Bertini I, Cantini F, Ciofi-Baffoni S (2010) Cellular copper distribution: a mechanistic systems biology approach. Cell Mol Life Sci 67, 2563-2589.

[4] Angeletti B, Waldron KJ, Freeman KB, Bawagan H, Hussain I, Miller CC, Lau KF, Tennant ME, Dennison C, Robinson NJ, Dingwall C (2005) BACE1 cytoplasmic domain interacts with the copper chaperone for superoxide dismutase- 1 and binds copper. J Biol Chem 280, 17930-17937.

[5] Wong PC, Waggoner D, Subramaniam JR, Tessarollo L, Bartnikas TB, Culotta VC, Price DL, Rothstein J, Gitlin JD (2000) Copper chaperone for superoxide dismutase is essential to activate mammalian $\mathrm{Cu} / \mathrm{Zn}$ superoxide dismutase. Proc Natl Acad Sci U S A 97, 2886-2891.

[6] Brady GF, Galban S, Liu X, Basrur V, Gitlin JD, ElenitobaJohnson KS, Wilson TE, Duckett CS (2010) Regulation of the copper chaperone CCS by XIAP-mediated ubiquitination. Mol Cell Biol 30, 1923-1936.

[7] Vassar R, Kovacs DM, Yan R, Wong PC (2009) The betasecretase enzyme BACE in health and Alzheimer's disease: regulation, cell biology, function, and therapeutic potential. $J$ Neurosci 29, 12787-12794.

[8] McLoughlin DM, Standen CL, Lau K-F, Ackerley S, Bartnikas TP, Gitlin JD, Miller CCJ (2001) The neuronal adaptor protein X11alpha interacts with the copper chaperone for SOD1 and regulates SOD1 activity. J Biol Chem 276, 9303-9307.

[9] Miller CC, McLoughlin DM, Lau KF, Tennant ME, Rogelj B (2006) The X11 proteins, Abeta production and Alzheimer's disease. Trends Neurosci 29, 280-285.

[10] Lee JH, Lau KF, Perkinton MS, Standen CL, Shemilt SJ, Mercken L, Cooper JD, McLoughlin DM, Miller CC (2003) The neuronal adaptor protein X11alpha reduces Abeta levels in the brains of Alzheimer's APPswe Tg2576 transgenic mice. J Biol Chem 278, 47025-47029.

[11] Mitchell JC, Perkinton MS, Yates DM, Lau KF, Rogelj B, Miller CC, McLoughlin DM (2010) Expression of the neuronal adaptor protein X11alpha protects against memory dysfunction in a transgenic mouse model of Alzheimer's disease. J Alzheimers Dis 20, 31-36.

[12] Iadecola C, Zhang F, Niwa K, Eckman C, Turner SK, Fischer E, Younkin S, Borchelt DR, Hsiao KK, Carlson GA (1999) SOD1 rescues cerebral endothelial dysfunction in mice overexpressing amyloid precursor protein. Nat Neurosci 2, 157161.

[13] Selkoe DJ (2001) Alzheimer's disease: Genes, proteins, and therapy. Physiol Rev 81, 741-766.

[14] Tamagno E, Bardini P, Obbili A, Vitali A, Borghi R, Zaccheo D, Pronzato MA, Danni O, Smith MA, Perry G, Tabaton M
(2002) Oxidative stress increases expression and activity of BACE in NT2 neurons. Neurobiol Dis 10, 279-288.

[15] Sun X, He G, Qing H, Zhou W, Dobie F, Cai F, Staufenbiel M, Huang LE, Song W (2006) Hypoxia facilitates Alzheimer's disease pathogenesis by up-regulating BACE1 gene expression. Proc Natl Acad Sci U S A 103, 18727-18732.

[16] Zhang X, Zhou K, Wang R, Cui J, Lipton SA, Liao FF, Xu H, Zhang YW (2007) Hypoxia-inducible factor 1a (HIF-1a)mediated hypoxia increases BACE1 expression and b-amyloid generation. J Biol Chem 282, 10873-10880.

[17] Carroll MC, Girouard JB, Ulloa JL, Subramaniam JR, Wong PC, Valentine JS, Culotta VC (2004) Mechanisms for activating $\mathrm{Cu}$ - and $\mathrm{Zn}$-containing superoxide dismutase in the absence of the CCS Cu chaperone. Proc Natl Acad Sci U S A 101, 5964-5969.

[18] Walter J, Fluhrer R, Hartung B, Willem M, Kaether C, Capell A, Lammich S, Multhaup G, Haass C (2001) Phosphorylation regulates intracellular trafficking of beta-secretase. J Biol Chem 276, 14634-14641.

[19] He X, Cooley K, Chung CH, Dashti N, Tang J (2007) Apolipoprotein receptor 2 and X11alpha/beta mediate apolipoprotein E-induced endocytosis of amyloid-beta precursor protein and beta-secretase, leading to amyloid-beta production. J Neurosci 27, 4052-4060.

[20] Setou M, Nakagawa T, Seog D-H, Hirokawa N (2000) Kinesin superfamily motor protein KIF17 and mLin-10 in NMDA receptor-containing vesicle transport. Science $\mathbf{2 8 8}$, 17961802.

[21] Saito Y, Sano Y, Vassar R, Gandy S, Nakaya T, Yamamoto T, Suzuki T (2008) X11 proteins regulate the translocation of APP into detergent resistant membrane and suppress the amyloidogenic cleavage of APP by BACE in brain. $J$ Biol Chem 283, 35763-35771.

[22] Ackerley S, Grierson AJ, Brownlees J, Thornhill P, Anderton BH, Leigh PN, Shaw CE, Miller CCJ (2000) Glutamate slows axonal transport of neurofilaments in transfected neurons. $J$ Cell Biol 150, 165-175.

[23] Lau KF, Howlett DR, Kesavapany S, Standen CL, Dingwall C, McLoughlin DM, Miller CCJ (2002) Cyclin-dependent kinase-5/p35 phosphorylates Presenilin 1 to regulate carboxyterminal fragment stability. Mol Cell Neurosci 20, 13-20.

[24] Hoey SE, Williams RJ, Perkinton MS (2009) Synaptic NMDA receptor activation stimulates alpha-secretase amyloid precursor protein processing and inhibits amyloid-beta production. J Neurosci 29, 4442-4460.

[25] Lau K-F, McLoughlin DM, Standen C, Miller CCJ (2000) $\mathrm{X} 11$ alpha and X11beta interact with presenilin-1 via their PDZ domains. Mol Cell Neurosci 16, 555-563.

[26] Parkin ET, Watt NT, Hussain I, Eckman EA, Eckman CB, Manson JC, Baybutt HN, Turner AJ, Hooper NM (2007) Cellular prion protein regulates beta-secretase cleavage of the Alzheimer's amyloid precursor protein. Proc Natl Acad Sci U S A 104, 11062-11067. 